Ambiente \& Água - An Interdisciplinary Journal of Applied Science
ISSN 1980-993X - doi:10.4136/1980-993X
www.ambi-agua.net
E-mail: ambi.agua@gmail.com

\title{
Rainfall zoning of Bahia State, Brazil: an update proposal
}

\author{
ARTICLES doi:10.4136/ambi-agua.2171
}

Received: 12 Aug. 2016; Accepted: 17 Dec. 2017

\author{
Yagho de Souza Simões ${ }^{1 *}$; Eduardo Henrique Borges Cohim Silva1; \\ Heráclio Alves de Araújo ${ }^{2}$ \\ ${ }^{1}$ Universidade Estadual de Feira de Santana (UEFS), Feira de Santana, BA, Brasil \\ Departamento de Tecnologia (DTEC). E-mail: yagho.ssimoes@gmail.com, \\ edcohim@gmail.com \\ ${ }^{2}$ Instituto do Meio Ambiente e Recursos Hídricos (INEMA), Salvador, BA, Brasil \\ Coordenação de Monitoramento de Recursos Ambientais e Hídricos (COMON). \\ E-mail: heraclio.araujo@gmail.com \\ *Corresponding author
}

\begin{abstract}
The state of Bahia's main climatic characteristic is the high spatial and chronological variability of precipitation. This heterogeneity may be used to determine of pluviometrically homogeneous areas that can define mesoregions in the state, since they allow better management of water resources and help in the elaboration of agricultural studies. The mesoregions already proposed by the scientific community for the state were based only on the annual precipitation in the proximity of the pluviometric stations. In this paper, besides these parameters, spatial and chronological rainfall distribution was considered, i.e., the Precipitation Concentration Degree (PCD) and Precipitation Concentration Period (PCP). The new zoning is based on an update of a study defined in 2000 that divided Bahia into eight mesoregions. Thus, 180 pluviometric stations were distributed throughout the state and grouped conforming to the division previously described. It was concluded that some stations of the same mesoregion had presented conflicting values for the analyzed parameters and, therefore, should not belong to the same area. Starting from an arrangement of the collection stations, considering their proximity, annual precipitation and statistical parameters, a new zoning for Bahia with 10 clusters was defined and validated through the statistical treatment of data.
\end{abstract}

Keywords: clusters, mesoregions, precipitation variability.

\section{Zoneamento pluviométrico do Estado da Bahia, Brasil: uma proposta de atualização}

\section{RESUMO}

O estado da Bahia possui como principal característica climática, a alta variabilidade espacial e temporal das precipitações. Essa heterogeneidade conduz à determinação de áreas pluviometricamente homogêneas, uma vez que estas permitem uma melhor gestão dos recursos hídricos e auxiliam na elaboração de estudos agrícolas. As propostas de mesorregiões já realizadas no meio científico para o estado se basearam apenas na precipitação anual e na proximidade dos postos pluviométricos. Porém nesse artigo, além desses parâmetros, foram utilizadas grandezas estatísticas que levam em consideração a distribuição espacial e temporal 
das chuvas, como o Grau de Concentração da Precipitação (GCP) e o Período de Concentração da Precipitação (PCP). O novo zoneamento se baseia em uma atualização de um estudo definido em 2000 que repartiu a Bahia em oito mesorregiões. Para isso, 180 postos pluviométricos foram distribuídos pelo estado e agrupados conforme a repartição descrita anteriormente. A partir da análise dos parâmetros de chuva para as estações de um mesmo agrupamento foi constatado que alguns postos pluviométricos, pertencentes a uma mesma mesorregião, apresentaram valores discrepantes para os parâmetros analisados e, portanto, não deveriam ocupar a mesma área. A partir de um ordenamento dos postos de coleta, levando em consideração a proximidade dos mesmos, a precipitação total anual e as grandezas estatísticas, foi definido um novo zoneamento para a Bahia com 10 agrupamentos e validação comprovada através de um tratamento estatístico dos dados.

Palavras-chave: agrupamentos, mesorregiões, variabilidade de precipitações.

\section{INTRODUCTION}

The state of Bahia has an area of approximately $600,000 \mathrm{~km}^{2}$, which presents a relief made up of plains, valleys and mountains, with altitude reaching $1400 \mathrm{~m}$ and, as its main climatic characteristic, high spatial and chronological variability of precipitation. According to Silva et al. (2012), this variability is justified not only by the influence of local geographic characteristics but also by the variations and intensity of the different meteorological systems that operate in the state at different times of the year.

This heterogeneity can be seen in Figure 1, which shows the spatial distribution of the month in which the average monthly precipitation reaches its maximum value. In addition, the annual precipitation distribution can be visualized for 5 meteorological stations representative of the pluviometric regime in distinct areas of the Northeast region of Brazil. The location of each station is indicated by the letters "Q" (Quixeramobim, Ceará), "O" (Olinda, Pernambuco), "S" (Salvador, Bahia), "C" (Caetité, Bahia) and "R" (Remanso, Bahia).

The three seasons that represent the behavior of Bahia's precipitation demonstrate satisfactorily the performance of the meteorological system's dynamics. It can be seen from Figure 1 that there are three rainy periods in the state. The first one occurs between November and March, with the highest rainfall volumes expected in December, represented by the Caetité station (the only rainy one) and Remanso station (the first and main rainy one). The precipitation occurrence in this period is mainly associated with the passage of the cold front, or traces of them, that advance through the southeast of the country, as well as the action of the South Atlantic Convergence Zone (SACZ), which is responsible for the transportation of humidity coming from the Amazon region towards Bahia, resulting in the rainfall's intensification, mainly in the central-south and west of the state.

The second rainy season is from February to May, with March being the month with the highest rainfall rates, represented by the Remanso station (as a secondary rainy season in the same region). In this quarter, the Intertropical Convergence Zone (ITCZ) is the key meteorological system responsible for the occurrence of these rains, mainly in the north of the Brazilian Northeast, reaching the north of Bahia.

The third and last rainy period of Bahia occurs between the months of April and July, with the highest rates being recorded in May, represented here by the Salvador station. During this period, the rains are concentrated in the east-central area of the state, originated by the humid winds coming from the Atlantic Ocean. However, the largest volumes are observed in the locations closest to the coast.

Regarding the annual rain distribution, the diversity of the factors involved in their generation and intensification in different regions of the state is evident. In the area closest to 
the coast, where rainfall maxima occurs in May, annual accumulation is superior to $1200 \mathrm{~mm}$. In the Chapada Diamantina region, where rainfall maxima occurs in December and March, annual accumulations reach $1000 \mathrm{~mm}$. In the west of the state, the average annual precipitation is high, over $1000 \mathrm{~mm}$; but it is concentrated mostly in a single period of the year. In many locations of the north, northeast, and south of the state, average annual precipitation does not reach $600 \mathrm{~mm}$. (Braga et al., 1998).

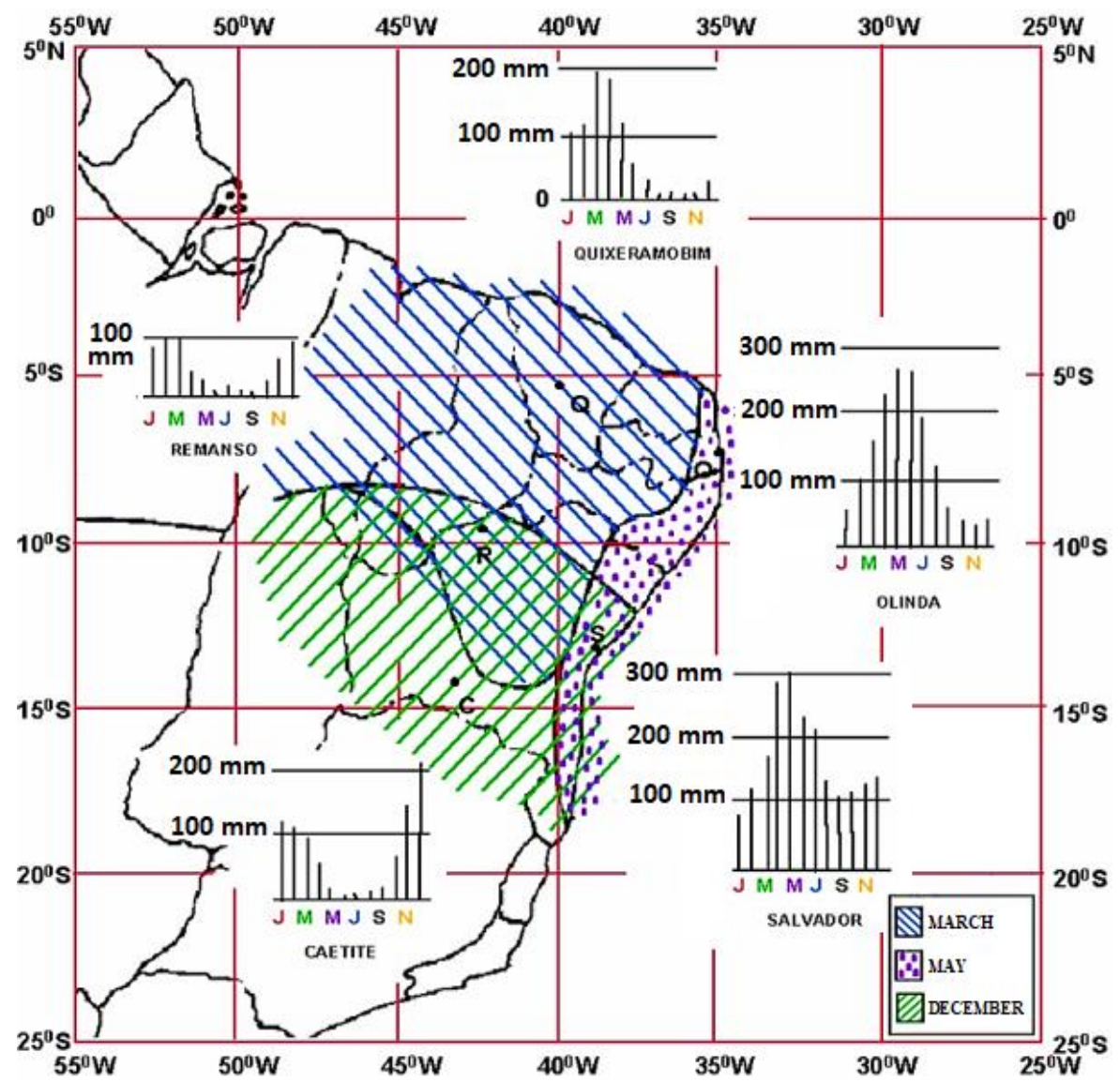

Figure 1. Spatial distribution of the month in which the average monthly precipitation reaches its maximum value in distinct areas of Northeast region of Brazil (CPTEC/INPE, 1986).

Considering this variability, some studies were developed with the purpose of verifying the existence of pluviometrically homogeneous areas, that can define mesoregions in the state. The determination of mesoregions is of utmost importance because it allows better management of water resources and helps in the elaboration of agricultural projects and studies (André et al., 2008). The agricultural area is intrinsically dependent on rainfall and therefore requires an adequate hydrological knowledge of the regions. According to Gopfert et al. (1993), precipitation is the major climatic risk factor for Brazilian agriculture. For this reason, the application of the zoning technique to define homogeneous areas helps the agricultural sector to define the best months for planting, avoiding crop losses.

The interest in determining rainy-homogeneous regions is demonstrated in works carried out in some places in Brazil and in the world. The following studies used the same grouping technique: the cluster analysis. Depending on the subjectivity of the researcher, one chooses the hierarchical or non-hierarchical technique for data processing. The studies that opted for the hierarchical analysis followed Ward's proposal (1963), while those that performed a nonhierarchical analysis adopted the k-means method.

\section{IPABH}

Rev. Ambient. Água vol. 13 n. 1, e2171 - Taubaté 2018 
Internationally, a range of studies identified homogenous regions based on precipitation. Kyselý et al. (2007) researched a way to identify homogeneous regions in the Czech Republic according to rainfall, applying the average-linkage clustering and Ward's method. The results pointed out four homogeneous regions. Firat et al. (2012) using the K-Means method, identified homogeneous regions in Turkey based on annual total precipitation series. Seven clusters were determined. Badr et al. (2016) subdivided Africa into homogeneous regions according to their precipitation regimes. Data processing techniques and grouping algorithms were employed in that case.

At the national level, some studies are prominent. Keller Filho et al. (2005) sought to identify mesoregions for Brazil from the application of the method referenced in the rainfall probability distribution and defined 25 homogeneous regions. A similar study was developed in northeastern Brazil. Guedes et al. (2010) used the cluster analysis non-hierarchical and Shannon entropy theory to evaluate the potential availability of water resources (PAWR), using rainfall data from 874 pluviometric stations. They concluded that the eastern coast of the region and the west of Maranhão State had the highest PAWR. However, the states of Ceará and Rio Grande do Norte and the central part of the Northeast presented a shortage of water resources.

The state of Rio de Janeiro was also divided into six mesoregions through 48 stations with a historical series of 30 years (1971-2000) (André et al., 2008). Freitas et al. (2013) carried out a zoning of Paraiba State, using the grouping technique for the climatic indexes (water, dryness and humidity) of 54 pluviometric stations, with a historical series from 1970 to 2000 . On the other hand, the state of Mato Grosso do Sul was divided into five regions by the mentioned grouping technique in the historical series (1954-2013) of 32 stations, defining three seasons for the area: dry, rainy and transitory (Teodoro et al., 2016). The State of Tocantins also went through a group analysis (cluster analysis using Ward's algorithm) and three pluviometrically homogeneous regions were definedaccording to Oliveira Júnior et al. (2017). Besides Terassi and Galvani (2017) identified homogeneous rainfall regions in the Eastern Watersheds of the State of Paraná, Brazil. The methodology applied was Ward's method for hierarchical grouping.

Regarding the state of Bahia, some studies were found, which proposed its subdivision. Braga et al. (1998) used daily series of 140 rainfall stations distributed in Bahia with a historical series of over 30 years. The cluster method, based on the ascending hierarchical method proposed by Ward (1963), was applied to identify similar areas from 10-day period data of each station. Nine sub-regions were proposed, as can be seen in Figure 2.

Dourado et al. (2013) used 92 pluviometric stations with a historical series of 30 years (1981-2010) to identify homogeneous pluviometric zones, applying the data-mining technique. The k-means algorithm was used, which is also based on cluster analysis of the stations monthly data. As a result, five similar regions were detected (Figure 3). Araújo and Rodrigues (2000), also using the cluster method for a precipitation data set of 140 pluviometric stations (19431983), determined eight mesoregions in Bahia, where there were similarities in the rainfall regimes' behavior, being denominated West, São Francisco, North, Chapada Diamantina, Southwest, South, Recôncavo and Northeast (Figure 4).

The majority of the previously mentioned studies were based only on the annual precipitation and in the proximity of the pluviometric stations to divide the state. However, the zoning in this research has the purpose of subsidizing urban and rural management planning activities. Therefore, it is of great relevance to consider the spatial and chronological rainfall distribution. Thus, by means of the Precipitation Concentration Degree (PCD) and Precipitation Concentration Period (PCP), the objective is to identify and classify pluviometrically homogeneous areas in the state of Bahia, based on the proposal described by Araújo and Rodrigues (2000). 


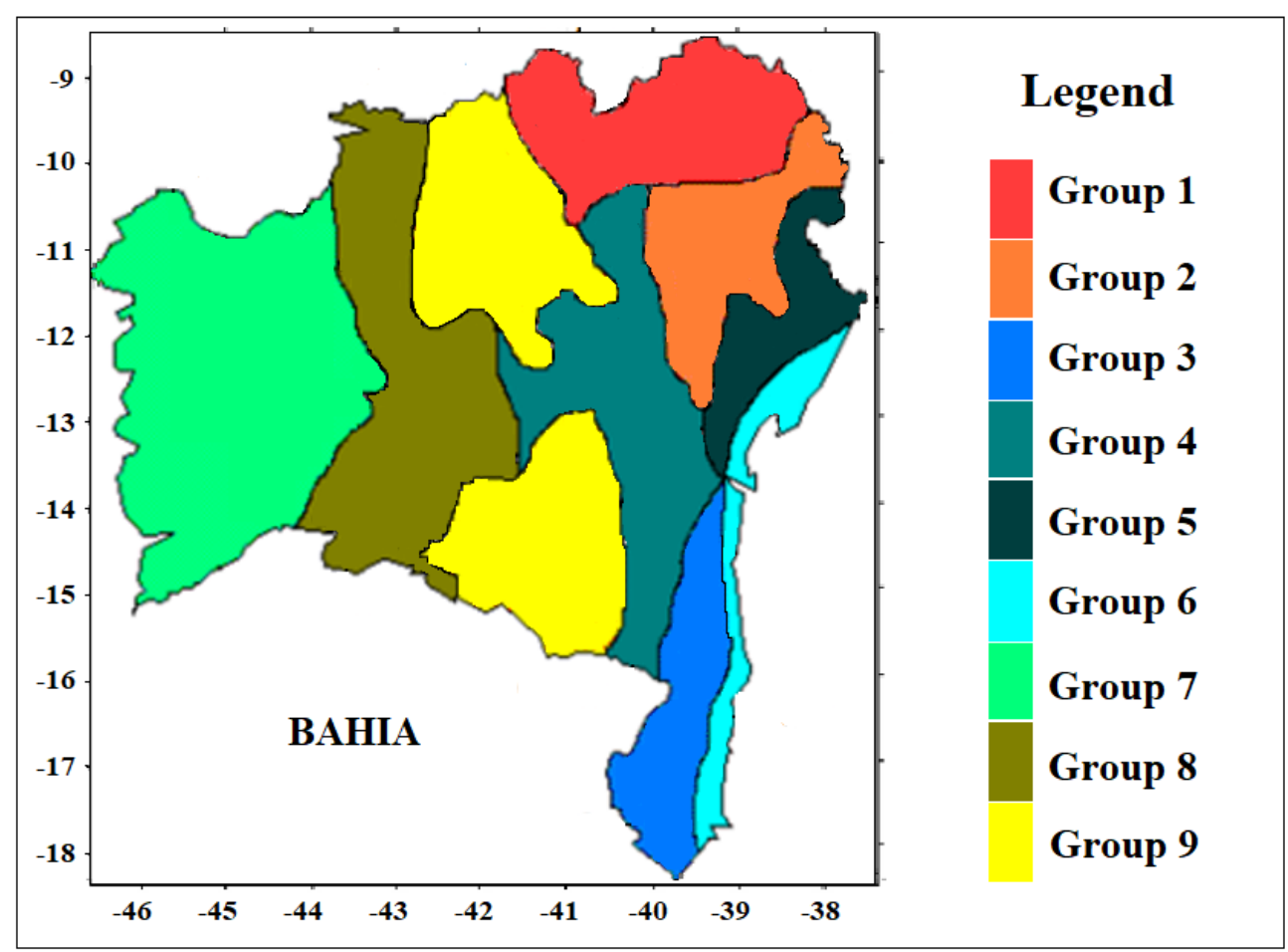

Figure 2. Rainfall zoning of Bahia proposed by the cluster method (Braga et al., 1998) (Adapted).

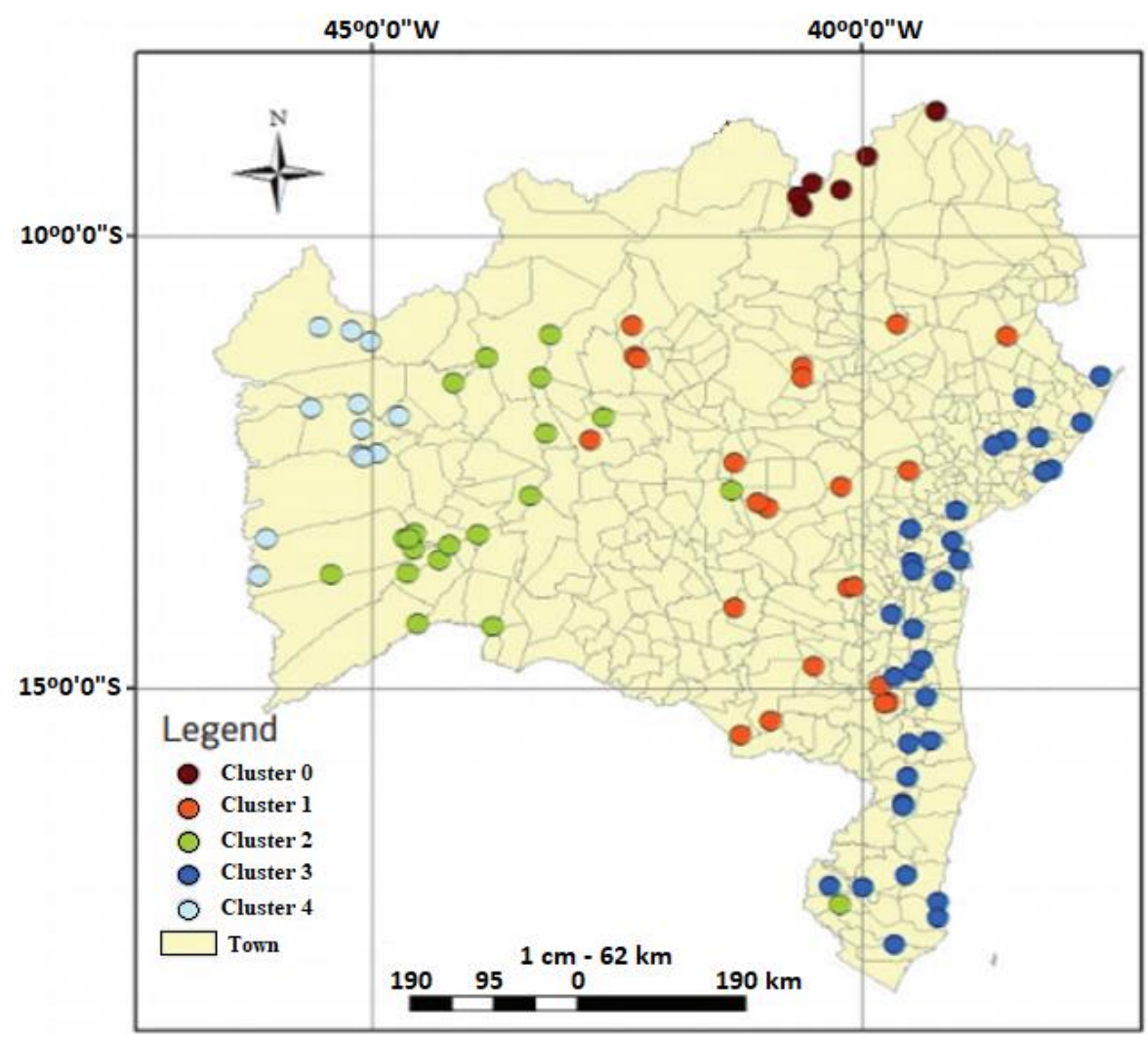

Figure 3. The climatic zoning of Bahia proposed by Dourado et al. (2013) (Adapted). 


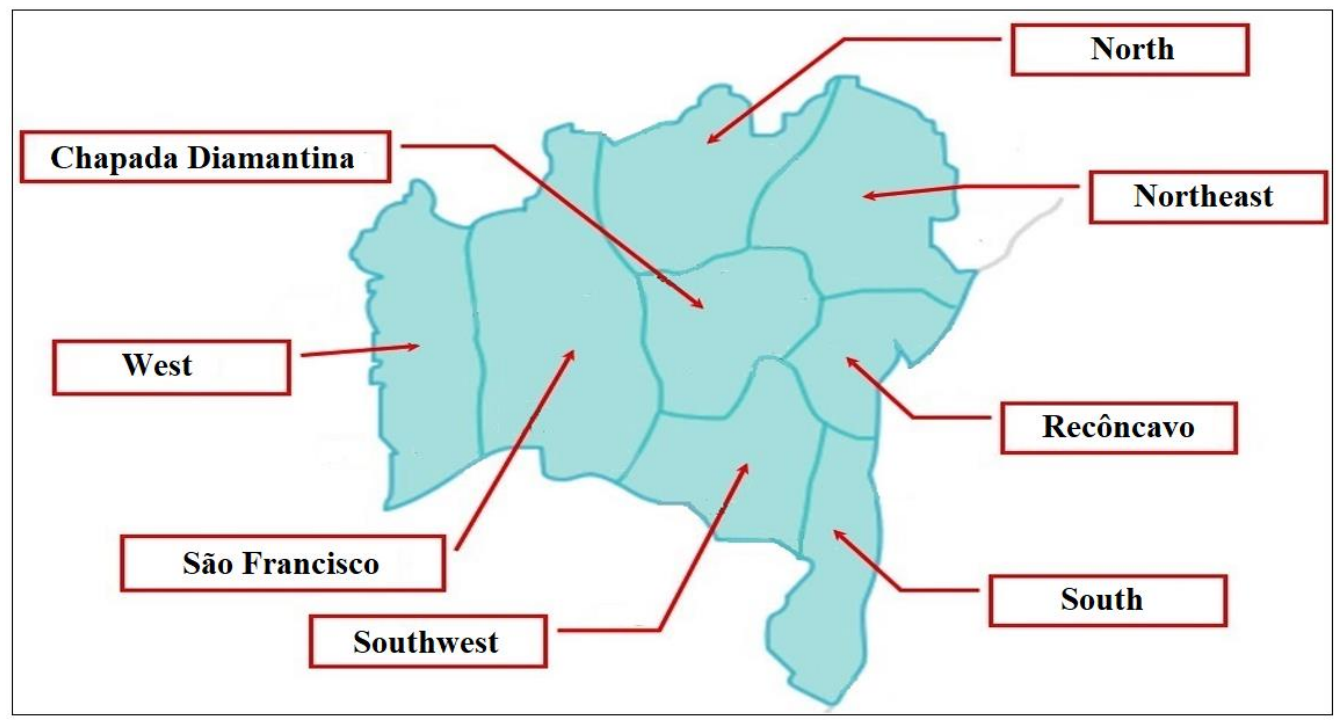

Figure 4. The climatic zoning of Bahia proposed by Araújo and Rodrigues (2000) (Adapted).

\section{MATERIALS AND METHODS}

The methodology used to delimitate the pluviometrically homogeneous mesoregions of the state was based on the behavior evaluation of rainfall in Bahia through definition of the statistical quantities PCD and PCP and annual precipitation. Maps were elaborated to spatialize such parameters using the tool ArcGis 10.2 to allow the definition of a new zoning.

\subsection{Available data}

The precipitation data used in this study consists of the historical series of 180 rainfall stations (Table 1).

The historical series of 180 rainfall stations are available in the Water Resources Database (BDRH) of the Environment and Water Resources Institute (INEMA) and the Hydrological Information System (HidroWeb) of the National Water Agency (ANA). Out of these stations, 92 have a 15-year historical series of daily rain data (1998-2012), while 88 have 33 years of data (1980-2012) (Table 1).

The 180 pluviometric stations spatial distribution is shown in Figure 5, showing good representativeness for the state of Bahia. It is curious that the number of stations used in this study, 180, exceeds the amount used in other studies already performed for the state, indicating its effective representation. In addition, the historical series employed are new, which already allows the incorporation of possible behavioral changes that may have happened and that were not considered in previous studies. 
Table 1. The 180 rainfall stations of Bahia, Brazil.

\begin{tabular}{|c|c|c|c|}
\hline \multicolumn{2}{|c|}{33 years historical series of daily rain data. } & \multicolumn{2}{|c|}{15 years historical series of daily rain data. } \\
\hline Alcobaça & Itajuípe (Piranji) & Anagé & Maracás \\
\hline Andaraí & Itamaraju & Antas & Marcionílio Souza \\
\hline Araças & Itanhém & Araci & Milagres \\
\hline Aratuipe & Itanhy & Baianópolis & Monte Santo \\
\hline Argoim & Itapebi & Baixa Grande & Morro do Chapéu \\
\hline Arrojado & Ituberá & Barra & Mucugê \\
\hline Barreiras & Jequié & Barra da Estiva & Mundo Novo \\
\hline Boqueirão & Juazeiro & Barra do Mendes & Mundo Novo-Ibiaporã \\
\hline Brotas De Macaúbas & Junco & Boa Vista do Tupim & $\begin{array}{l}\text { Muquém de São } \\
\text { Francisco }\end{array}$ \\
\hline Buracica & Lagoa Do Boi & Bom Jesus da Lapa & Palmas de Monte Alto \\
\hline Camacan (Vargito) & Lomanto Junior & Boninal & Paramirim \\
\hline Campo Dos Cavalos & Lucaia (Campos Sales) & Bonito & Paripiranga \\
\hline Cândido Sales & Mascote & Brumado & Paulo Afonso \\
\hline Carinhanha & Medeiros Neto & Caculé & Pedro Alexandre \\
\hline Cipó & Miguel Calmon (Djalma Dutra) & Caetité & Piatã \\
\hline Colônia Do Formoso & Mocambo & Cafarnaum & Planaltino \\
\hline Correntina & Morpará & Canarana & Ponto Novo \\
\hline Corte Grande & Mundo Novo & Cansanção & Potiraguá \\
\hline Derocal & Mutuípe & Casa Nova & Remanso \\
\hline Emboacica & Nazaré & Conceição do Coité & Riachão do Jacuípe \\
\hline Fazenda Bom Jardim & Nilo Peçanha & Condeúba & Riacho de Santana \\
\hline Fazenda Cabaceiras & Nova Vida - Montante & Coronel João Sá & Ribeira do Pombal \\
\hline Fazenda Coqueiro & Pedrinhas & Entre Rios & Rio Real \\
\hline Fazenda Iguaçu & Ponte Br-242 & Euclides da Cunha & Rodelas \\
\hline Fazenda Macambira & Ponte Serafim - Montante & Feira de Santana & Ruy Barbosa \\
\hline Fazenda Manaus & Porto & Gentio do Ouro & Santa Bárbara \\
\hline Fazenda Nancy & Porto Novo & Guanambi & Santa Brígida \\
\hline Fazenda Porto Alegre & Prado & Heliópolis & Santaluz \\
\hline Fazenda Redenção & Próximo A Curaça II & Ibicuí & Santana \\
\hline Fazenda Refrigério - Jusante & Queimadas & Ibitiara & Sátiro Dias \\
\hline Floresta Azul & Rio Verde II & Ibititá & Saúde \\
\hline Formosa Do Rio Preto & Santa Cruz Da Vitória & Ipiaú & Seabra \\
\hline França & Santa Inês & Ipirá & Senhor do Bonfim \\
\hline Gameleira & Santa Luzia & Irecê & Sento Sé \\
\hline Gatos & Santa Maria Da Vitória & Itaberaba & Serra do Ramalho \\
\hline Helvécia (Efbm) & Santo Antônio & Itambé & Serrinha \\
\hline Iaçu & São José & Itapetinga & Souto Soares \\
\hline Ibipetuba & São José Do Prado & Itapicuru & Tucano \\
\hline Ibó & São Sebastião & Itiruçu & Uauá \\
\hline Ibotirama & Sítio Grande & Ituaçu & Uibaí \\
\hline Inhambupe & Teodoro Sampaio & Jacobina & Umburanas \\
\hline Inhobim & Tiririca & Jeremoabo & Urandi \\
\hline Itaeté & Valença & Livramento de Nossa Senhora & Utinga \\
\hline \multirow[t]{3}{*}{ Itajú Do Colônia } & Wenceslau Guimarães & Macarani & Vitória da Conquista \\
\hline & & Macaúbas & Wanderley \\
\hline & & Mairi & Xique-Xique \\
\hline
\end{tabular}




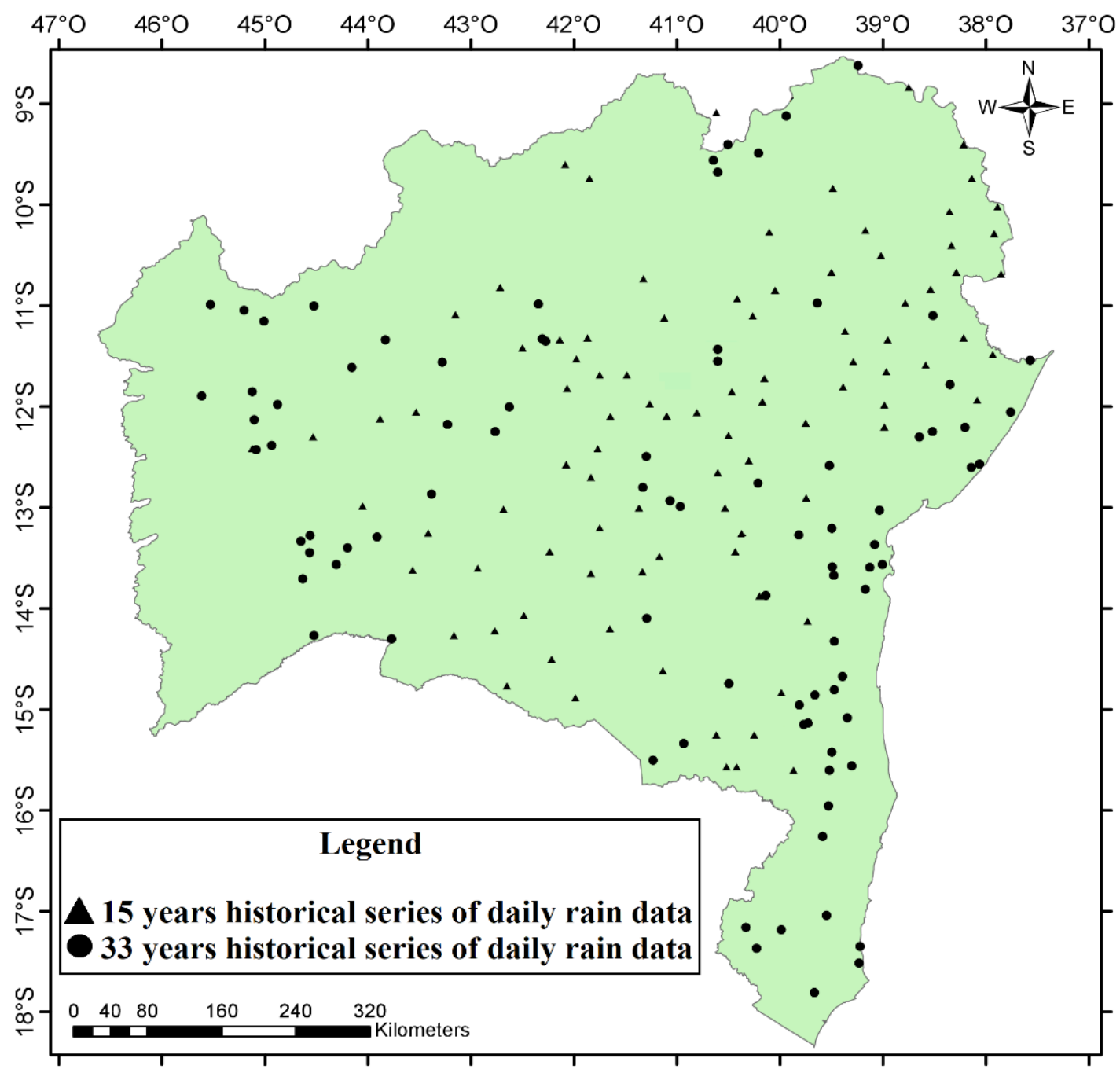

Figure 5. Spatial Distribution of the pluviometric stations of Bahia, Brazil (Personal collection).

\subsection{Data processing}

An analysis of the annual total precipitation data was executed in order to verify the existence of gaps, as well as the possibility of filling them, using some method or technique that would best fit for each station. Then, a consistency analysis was completed.

For the period when there was no precipitation data, they were estimated from the gapfilling procedures using the regional means method developed by Paulhus and Kohler (1952), which is based on the pluviometric records of the three nearest and evenly spaced stations from the failed registry station.

The first procedure is used in cases where the annual normal precipitation at each of the three adjacent stations does not exceed $10 \%$ of the normal annual precipitation of the failed station in the series. Thus, the estimated precipitation value is the result of the arithmetic mean of the three stations' rainfalls.

When the annual normal precipitation at one of the adjacent stations exceeds $10 \%$ of the normal annual precipitation of the failed station, a second procedure is used. In these cases, the estimated precipitation is determined by the weighted average of the three contiguous stations' registers, where the weights are the ratios between normal annual precipitation. Therefore, the daily precipitation $(\mathrm{P})$ at the $\mathrm{x}(\mathrm{Px})$ station is calculated by (Equation 1): 
$P_{x}=\frac{1}{3}\left[\frac{N x}{N a} P a+\frac{N x}{N b} P b+\frac{N x}{N c} P c\right]$

Where, "N" is the annual normal precipitation and the letters "a", "b" and "c" represent the adjacent stations to station $\mathrm{x}$.

After filling the gaps in the precipitation data series, they were submitted to a consistency analysis within a regional view, which allowed the determination of the homogeneity degree of the available data in a station with respect to the observations recorded in adjacent stations.

In this paper, the Double-Mass Method was applied, one of the best-known methods of consistency analysis for precipitation data. Through this method, it is possible to verify if changes happened in the precipitation performance over time, or even at the collection site (Bertoni and Tucci, 2007). According to these authors, the method is applied as follows: the stations of a microregion are separated, and then their annual precipitation totals are accumulated and plotted in a Cartesian system, where in the abscissa axis is included the accumulated annual precipitation of the microregion and, in the ordinate axis, the accumulated totals of each station.

There should be proportionality between the accumulated totals of the analyzed stations and the accumulated average totals in the microregion so that the points align along a straight line. If a change in slope is identified, it is established as follows: systematic errors, change in the collection conditions or existence of a real physical cause, such as climate change in a region.

\subsection{PCD and PCP Calculation Method}

The PCD is a quantity that reflects the degree to which the total precipitation is distributed throughout the 12 months of the year. Its value ranges from 0 to 1 . Values near 0 represent more-distributed rainfall, while values close to 1 indicate that rain is concentrated in an abbreviated period. The PCP is also a statistical quantity given in degrees that measures the month in which the precipitated total was concentrated in the year.

The calculation principle of the PCD and PCP is based on a vector analysis. According to Xumei et al. (2010), the monthly precipitation is considered a vector whose direction and magnitude for a year can be seen as a $360^{\circ}$ circumference.

Each year has 12 months, so each month assumes a value of $30^{\circ}$, as can be seen in Table 2. Starting from January with $0^{\circ}$ until December with $330^{\circ}$, being the coverage of each month $( \pm) 15^{\circ}$.

Table 2. Relationship between the month and the PCP (Xumei et al., 2010) (Adapted).

\begin{tabular}{cccccc}
\hline Month & PCP & Month & PCP & Month & PCP \\
\hline January & $0^{\circ}$ & May & $120^{\circ}$ & September & $240^{\circ}$ \\
February & $30^{\circ}$ & June & $150^{\circ}$ & October & $270^{\circ}$ \\
March & $60^{\circ}$ & July & $180^{\circ}$ & November & $300^{\circ}$ \\
April & $90^{\circ}$ & August & $210^{\circ}$ & December & $330^{\circ}$ \\
\hline
\end{tabular}

Because it is a vector, the monthly precipitation has horizontal projections, $\mathrm{R}_{\mathrm{x}}$, and vertical projections, $\mathrm{R}_{\mathrm{y}}$, that allow the calculation of these quantities as follows (Equations 2, $3,4,5$ e 6$)$ :

$$
\begin{aligned}
\mathrm{R}_{\mathrm{i}} & =\sum \mathrm{r}_{\mathrm{ij}} \\
\mathrm{R}_{\mathrm{xi}} & =\sum \mathrm{r}_{\mathrm{ij}} \cdot \sin \theta_{\mathrm{j}}
\end{aligned}
$$




$$
\begin{aligned}
& \mathrm{R}_{\mathrm{yi}}=\sum \mathrm{r}_{\mathrm{ij}} \cdot \cos \theta_{\mathrm{j}} \\
& \mathrm{PCP}_{\mathrm{ij}}=\tan ^{-1} \frac{\mathrm{R}_{\mathrm{xi}}}{\mathrm{R}_{\mathrm{yi}}} \\
& \mathrm{PCD}_{\mathrm{ij}}=\frac{\sqrt{\mathrm{R}^{2}{ }_{\mathrm{xi}}+\mathrm{R}^{2} \mathrm{yi}}}{\mathrm{R}_{\mathrm{i}}}
\end{aligned}
$$

Where " $\mathrm{i}$ " is the year of the historical series and "j" represents the month. The variable $r_{i j}$ demonstrates the precipitation in month "j" of the year " $i "$ and $\theta_{j}$ represents the studied month.

\subsection{Evaluation of mesoregions defined in 2000}

The that main objective of this study was to develop a zoning proposal based on the division defined by Araújo and Rodrigues (2000). Thus, it was necessary to evaluate the homogeneity of the annual and monthly rainfall data, in addition to statistical quantities such as PCD and PCP for the 180 pluviometric stations divided in the eight mesoregions proposed in 2000. Therefore, two methodologies were adopted by authors.

The first one is to develop electronic spreadsheets for each of the eight mesoregions, where the data collection stations were grouped with the following characteristics: average PCD, average PCP, average total precipitation and average precipitation of each month. The second methodology used consisted of the boxplot tool to evaluate the behavior of the PCD series and annual precipitation of all the stations of each mesoregion. The boxplot is a graphing tool used to check the variation of a variable in a data series. In the abscissa axis are the factors of interest, which in this study will be the stations, and in the ordinate axis is the variable to be analyzed, which in this case are the PCD and precipitation.

\section{RESULTS AND DISCUSSION}

\subsection{Analysis of mesoregions defined in 2000}

After grouping the 180 collection stations in the eight mesoregions proposed by Araújo and Rodrigues (2000) and attaching the respective rainfall parameters, it was sought to identify the similarities and/or differences between the pluviometric stations in these areas. The behavior of the annual precipitation and PCD for the North mesoregion is shown in Table 3 and PCD for the West mesoregion is shown in Figure 6, where there was uniformity between these quantities. Such behavior suggests that the meteorological systems responsible for the occurrence of these rains act in a homogeneous way, both in the area of each mesoregion and in the period throughout the year.

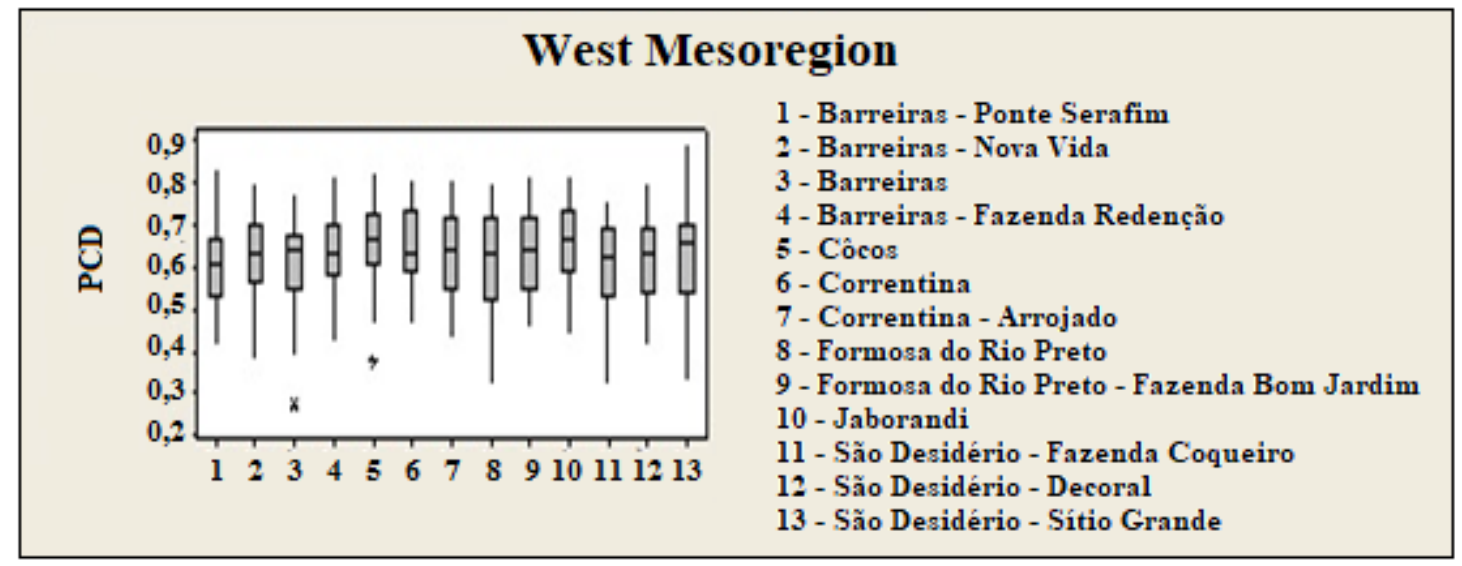

Figure 6. Boxplot for PCD of the West Mesoregion (Personal collection). 
Table 3. Partial of the North Mesoregion Spreadsheet with precipitation and PCD values.

\begin{tabular}{lccccccc}
\hline Month & Casa Nova & Ibititá & Irecê & Juazeiro- Junco & Remanso & Santo Sé & Uibaí \\
\hline January & 83,5 & 88,5 & 102,1 & 85,4 & 101,7 & 98,2 & 124,4 \\
February & 88,1 & 86,8 & 98,7 & 85,5 & 105,2 & 103,4 & 88,0 \\
March & 104,4 & 79,3 & 98,3 & 90,3 & 97,7 & 135,1 & 120,7 \\
April & 41,0 & 31,3 & 48,0 & 32,1 & 42,2 & 62,9 & 46,4 \\
May & 16,1 & 11,5 & 16,1 & 13,6 & 4,2 & 8,8 & 11,6 \\
June & 2,2 & 1,4 & 0,4 & 6,7 & 1,9 & 0,5 & 0,0 \\
July & 1,0 & 0,0 & 0,3 & 3,3 & 0,3 & 0,2 & 0,0 \\
August & 0,9 & 0,3 & 0,0 & 1,0 & 0,0 & 0,0 & 0,0 \\
September & 4,1 & 2,5 & 4,8 & 1,8 & 1,9 & 0,8 & 4,3 \\
October & 24,5 & 28,6 & 27,2 & 12,6 & 21,0 & 15,5 & 37,1 \\
November & 42,3 & 100,4 & 105,9 & 52,7 & 75,6 & 72,1 & 84,6 \\
December & 59,4 & 112,6 & 108,0 & 64,0 & 47,1 & 56,5 & 122,1 \\
\hline Total & 467,5 & 543,2 & 609,8 & 449,2 & 498,8 & 554,0 & 639,2 \\
PCD & 0,61 & 0,63 & 0,61 & 0,62 & 0,648 & 0,65 & 0,63 \\
\hline
\end{tabular}

Source: Personal collection.

In the other mesoregions of the state (São Francisco, Chapada Diamantina, Southwest, Northeast, Recôncavo and South) the climatic diversity was evident, especially in relation to the rainfall regime, where there were significant variations in annual totals in the same area, as in the Northeast mesoregion, presented in Table 4. It can be observed in this Table that the lowest value for average annual total precipitation was recorded in the municipality of Coronel João Sá (with $240.9 \mathrm{~mm}$ ) and the highest value $(1706.1 \mathrm{~mm})$ was registered in the municipality of Esplanada (Corte Grande Station).

The same behavior in the total annual precipitation can also be seen in the Boxplot of the Recôncavo mesoregion (Figure 7), where it indicates a heterogeneity in the rainfall volume distribution in the area. Therefore, a great variety of characteristics can be perceived for a same mesoregion that should have data uniformity.

Table 4. Partial of the Northeast Mesoregion Spreadsheet.

\begin{tabular}{lcccccccc}
\hline Month & Ibó & Antas & $\begin{array}{c}\text { Conceição } \\
\text { do Coité }\end{array}$ & Curaçá & Cipó & $\begin{array}{c}\text { Coronel } \\
\text { João Sá }\end{array}$ & $\begin{array}{c}\text { Entre } \\
\text { Rios }\end{array}$ & $\begin{array}{c}\text { Corte } \\
\text { Grande }\end{array}$ \\
\hline January & 86,3 & 63,8 & 58,6 & 93,0 & 35,4 & 17,6 & 97,3 & 75,3 \\
February & 77,5 & 61,6 & 45,6 & 71,8 & 45,2 & 23,9 & 81,1 & 94,9 \\
March & 111,5 & 60,5 & 37,1 & 94,6 & 67,9 & 26,7 & 74,0 & 114,1 \\
April & 65,6 & 81,9 & 35,2 & 47,1 & 58,2 & 14,5 & 133,6 & 215,3 \\
May & 29,3 & 114,5 & 44,6 & 19,0 & 56,5 & 39,4 & 152,0 & 248,0 \\
June & 12,0 & 121,5 & 61,1 & 7,2 & 60,1 & 37,5 & 161,1 & 235,6 \\
July & 9,6 & 102,7 & 36,8 & 7,1 & 55,6 & 29,6 & 148,5 & 188,1 \\
August & 4,6 & 88,6 & 31,6 & 2,0 & 33,8 & 21,8 & 107,5 & 162,8 \\
September & 1,5 & 37,0 & 19,1 & 1,6 & 25,0 & 8,6 & 85,9 & 110,7 \\
October & 9,5 & 33,3 & 38,0 & 3,8 & 28,0 & 16,5 & 59,8 & 83,5 \\
November & 31,2 & 20,9 & 44,4 & 34,9 & 47,5 & 2,2 & 58,1 & 87,6 \\
December & 53,8 & 40,0 & 38,4 & 68,2 & 40,8 & 2,6 & 25,4 & 90,3 \\
\hline Total & 492,4 & 826,3 & 490,6 & 450,2 & 554,1 & 240,9 & 1184,3 & 1706,1 \\
PCD & 0,58 & 0,30 & 0,08 & 0,62 & 0,16 & 0,34 & 0,27 & 0,29 \\
\hline
\end{tabular}

Source: Personal collection. 


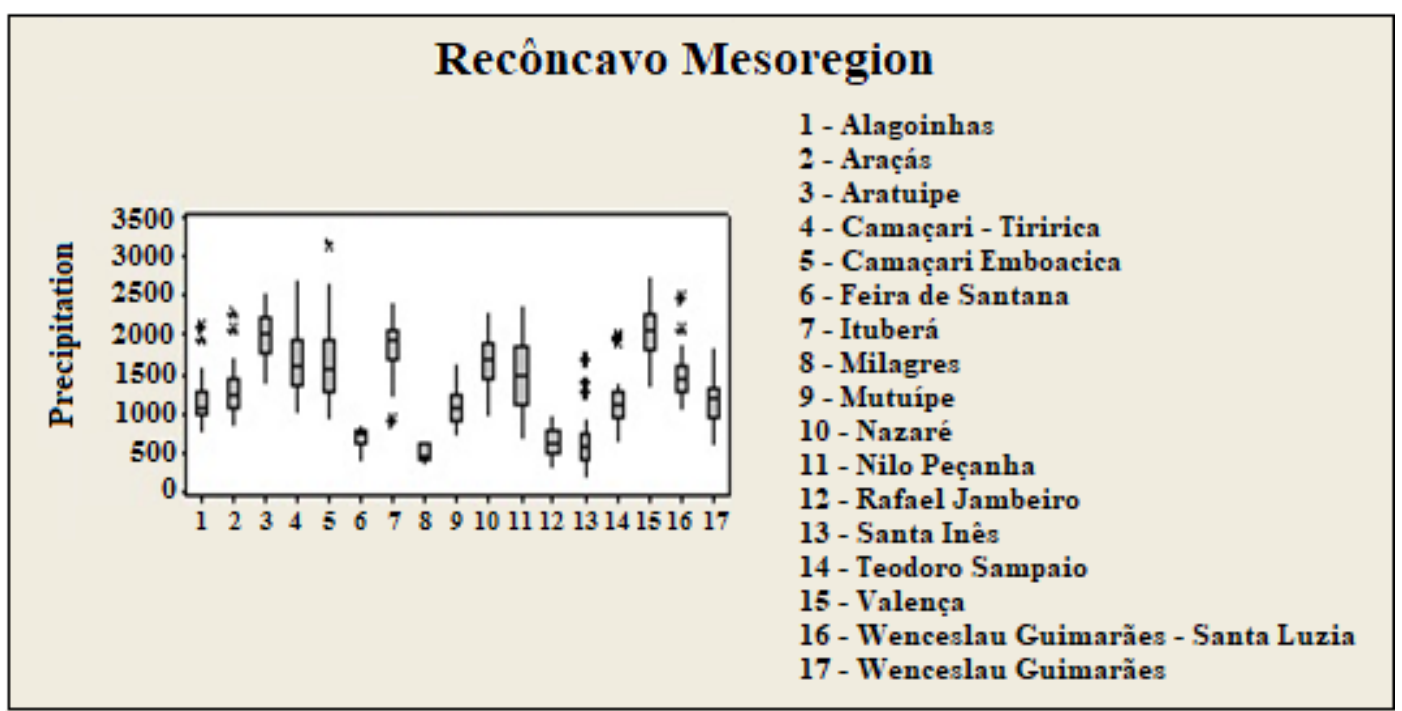

Figure 7. Boxplot for Precipitation of the West Mesoregion (Personal collection).

As for PCD, there were also significant variations in the Northeast mesoregion, such as the lowest value of $(0,08)$ in the pluviometric station of Conceição de Coité and the highest of (0.62) in the pluviometric station Curaçá. Besides the Northeast and Recôncavo, there were also significant variations in annual precipitation totals and in PCD in the São Francisco, Chapada Diamantina, Southwest and South mesoregions. Such behavior in these quantities indicates the complexity in the performance and influence of the different meteorological systems in the state during the year, as mentioned by Kousky (1979) and Araújo and Rodrigues (2000).

Out of the Brazilian Northeast states, Bahia has the greatest diversity in the climatic conditions of the region. Therefore, each mesoregion of the state, as defined by Araújo and Rodrigues (2000), can be influenced by one or more meteorological systems, in a single period or in distinct periods throughout the year, acting with more or less intensities in different areas of each mesoregion. A clear example of this variability can be found in the municipalities of Valença and Santa Inês, both in the Recôncavo mesoregion, which are influenced by the same meteorological systems, in this case, cold fronts and breezes. However, the location of these municipalities is also one of the factors that influence the behavior of the rains, since those that are closer to the coast (e.g., Valença) have systems that act with more intensity. Consequently, the precipitation volumes are larger. Unlike the municipality of Santa Inês, relatively distant from the coast, where the same systems operate, although with less intensity, resulting, therefore, in lower rainfall volume.

\subsection{Analysis of PCD and PCP precipitation results}

Due to the lack of PCD and precipitation uniformity for the great majority of the stations in a same mesoregion, it was decided to study separately each of the main quantities that describe the rains' behavior.

\subsubsection{Annual Precipitation}

The spatial distribution of average annual precipitation is shown in Figure 8A. It is pointed out that this quantity varies between $241.0 \mathrm{~mm}$, in the municipality of Coronel João Sá (located in the Northeast mesoregion), at $2049.4 \mathrm{~mm}$, in the municipality of Valença (located in the Recôncavo mesoregion). It was also observed that the most expressive rainfall volumes have a greater distribution in the South and West mesoregions and in the localities closest to the Recôncavo coast and to the Northeast of the state. On the other hand, the smaller volumes are present in the North mesoregion, with precipitations around $500 \mathrm{~mm}$. These results agree with the study prescribed in Braga et al. (1998). 


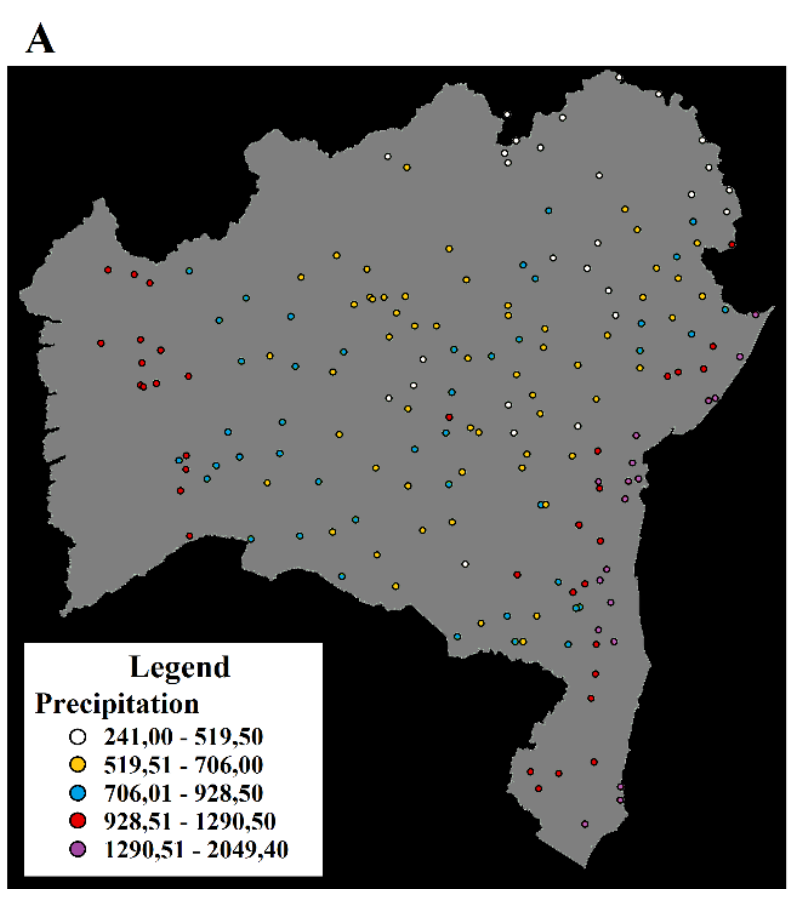

\section{B}

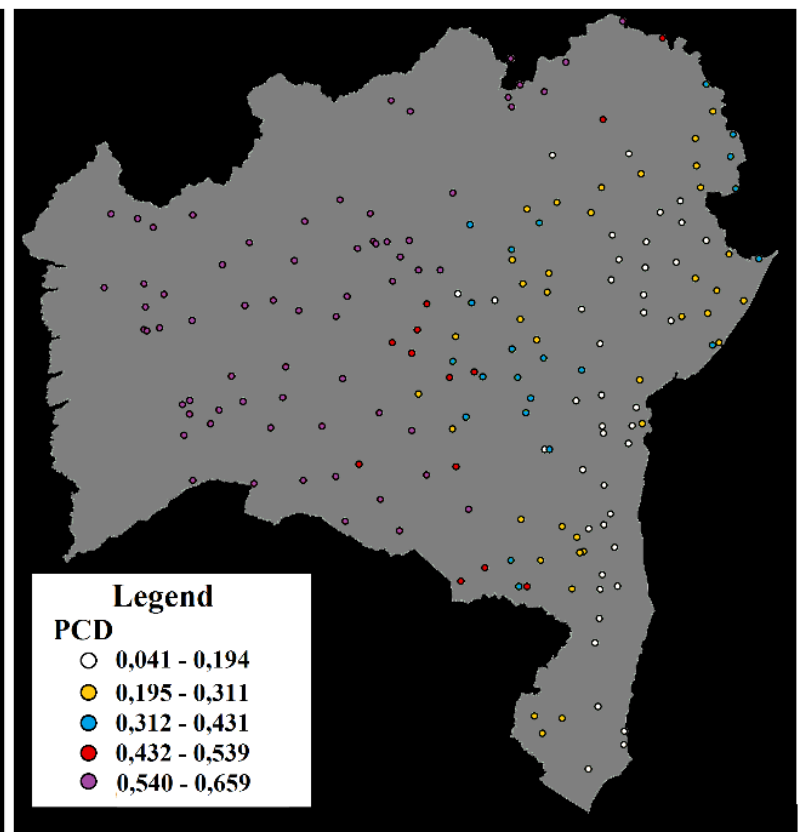

Figure 8. Spatial Distribution: Precipitation (A); PCD (B) (Personal collection).

\subsubsection{Degree of precipitation concentration (PCD)}

The PCD spatial distribution is shown in Figure $8 \mathrm{~B}$, in which there is considerable variation in concentration, such as the lowest value found for the Prado municipality station (with 0.041) and the highest value in the Xique-Xique municipality station (with 0.659). This variation demonstrates the great climatic diversity in Bahia, mainly in relation to the rainfall regime, which suggests the performance and influence of different meteorological systems with divergent characteristics and in distinct areas of the state, such as in the central-west and north where the highest concentration was verified.

It can be observed in these figures that high precipitation values do not mean homogeneity in its distribution over the years, as can be observed in the west and near the coast (Zona da Mata of Bahia), which are the areas that normally concentrate the largest precipitation accumulations. However, the PCD of these two areas is significantly different, i.e., in the west of the state, this degree is high, which characterizes the performance or influence of the meteorological systems that cause the rains in a single period during the year. In Zona da Mata, where PCD is low, rainfall usually occurs during most of the year, indicating, therefore, the performance or influence of meteorological systems with different characteristics, but in distinct periods.

In addition, with respect to the two properties analyzed in the last two items, regions with similar values are pointed out, indicating possible division of the state, using these characteristics as parameters.

\subsubsection{Precipitation concentration period (PCP)}

From the statistical analysis, it was observed that the PCP of the 180 pluviometric and meteorological stations showed little variation. Given that the coverage degree of each month is approximately $15^{\circ}$, it was verified that out of the total of 180 points, 168 presented intense rains in the period between November and February, with PCP oscillating between $300^{\circ}-30^{\circ}$, thus characterizing summer rains occurring in most part of Bahia. These rains are part of the first rainy season, with the main causes being the passage of cold fronts and the action of the South Atlantic Convergence Zone (SACZ), which brings moisture to the Amazon region, resulting in rainfall intensification, mainly in the central-south and west of the state. 
On the other hand, in March, only 9 (nine) of these stations had a higher concentration, with PCP around $60^{\circ}$. This month, the systems that operate during the summer are already losing strength, thus beginning the second rainy period of the state, mainly in the northern part, where the Intertropical Convergence Zone (ITCZ) is the meteorological system that influences the time with more intensity. In October and April, the number of points was even smaller, two (2) and one (1), respectively.

Therefore, it was verified that the PCP quantity had greater significance in the period of the summer rains, when it defined the central-south and west range of the state as the greatest concentration area during that season. In other periods of the year, this quantity does not have a great influence in the definition of areas with periods of greater rainfall concentrations.

\subsection{New clusters proposed}

Considering the results obtained with the PCD, the annual precipitation and PCP analysis in the eight mesoregions defined by Araújo and Rodrigues (2000), where some variations and inconsistencies in their spatializations were found, the need for a refinement of these mesoregions arose. Thus, we propose an update of the zoning developed in 2000. Using the same parameters, it was possible to amplify these areas, allowing a better representation of the State rainfall regime during the year. Therefore, a subdivision of 10 clusters is proposed (Figure 9). Municipal limits were disregarded.

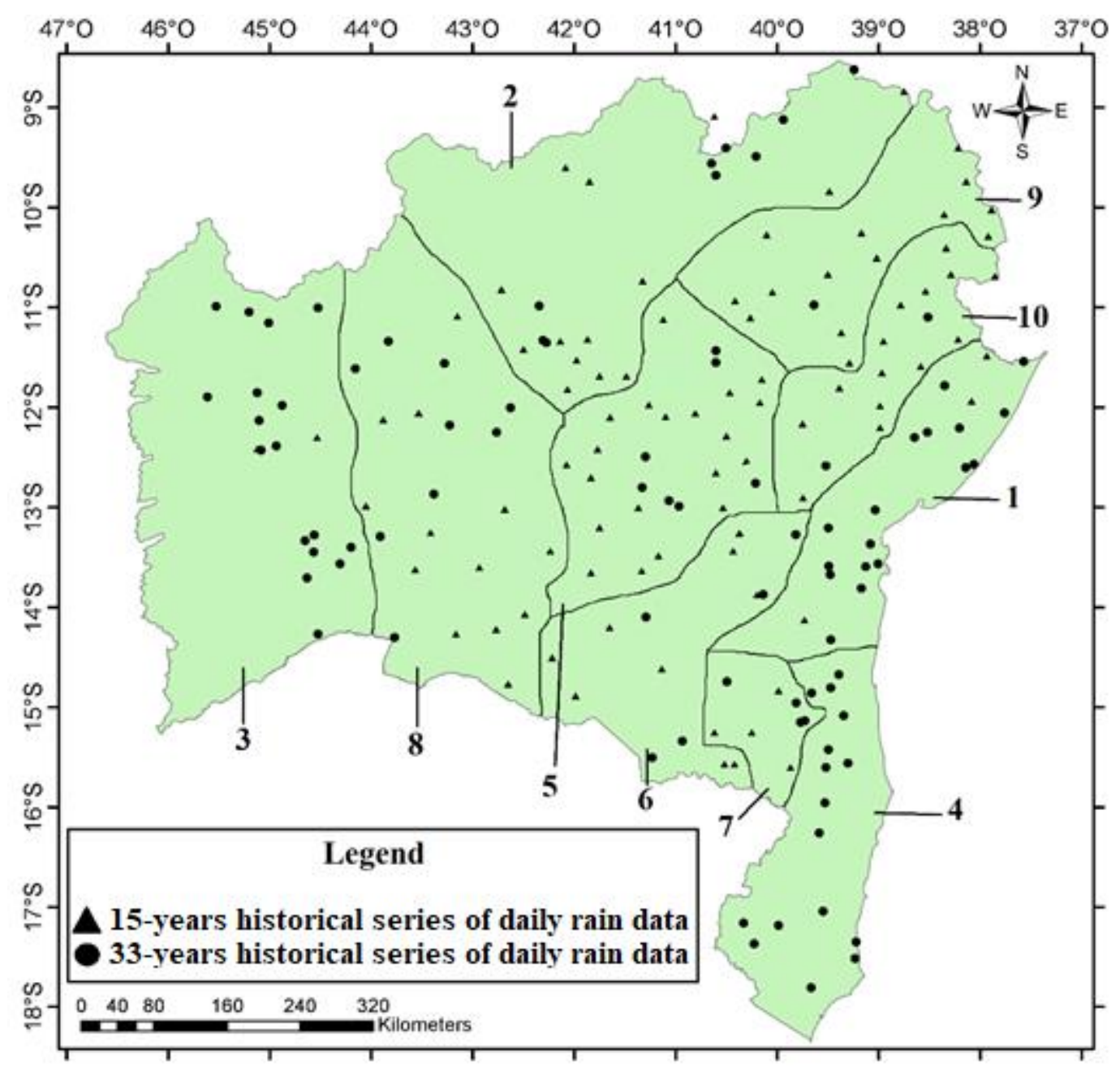

Figure 9. New Clusters proposed for Bahia, Brazil (Personal collection). 
When comparing the map of the new clusters (Figure 9) with the map of the mesoregions defined by Araújo and Rodrigues (Figure 4), the most significant changes occurred in the Northeast and the Southwest mesoregions of the state, where the creation of two more areas was proposed.

The insertion of one more area in the Northeast sector, besides the expansion to the north of Recôncavo mesoregion, is mainly due to the strong gradient in annual precipitation totals, where the values vary between $1200 \mathrm{~mm}$ in the localities closest to the coast (between the states of Bahia and Sergipe) and $700 \mathrm{~mm}$ in the more distant localities (in the border of Bahia and the west of Sergipe), as shown in Figure 10 Even if this area is influenced by the same meteorological systems, the intensity with which they act is quite diverse, being larger in the coastal strip (bringing more expressive rains) and reducing, significantly, when moving towards the interior.

In the southwest of Bahia, the creation of one more area was also due to the strong gradient in annual precipitation totals, mainly in the South mesoregions range, where accumulations vary between $1300 \mathrm{~mm}$ and $2200 \mathrm{~mm}$, and Southwest, where accumulations vary between 600 $\mathrm{mm}$ and $800 \mathrm{~mm}$. Therefore, in the new area (or new clustering), which is also influenced by the same meteorological systems of the South and Southwest mesoregions, the annual rainfall accumulations vary between $800 \mathrm{~mm}$ and $1300 \mathrm{~mm}$ (Figure 10).

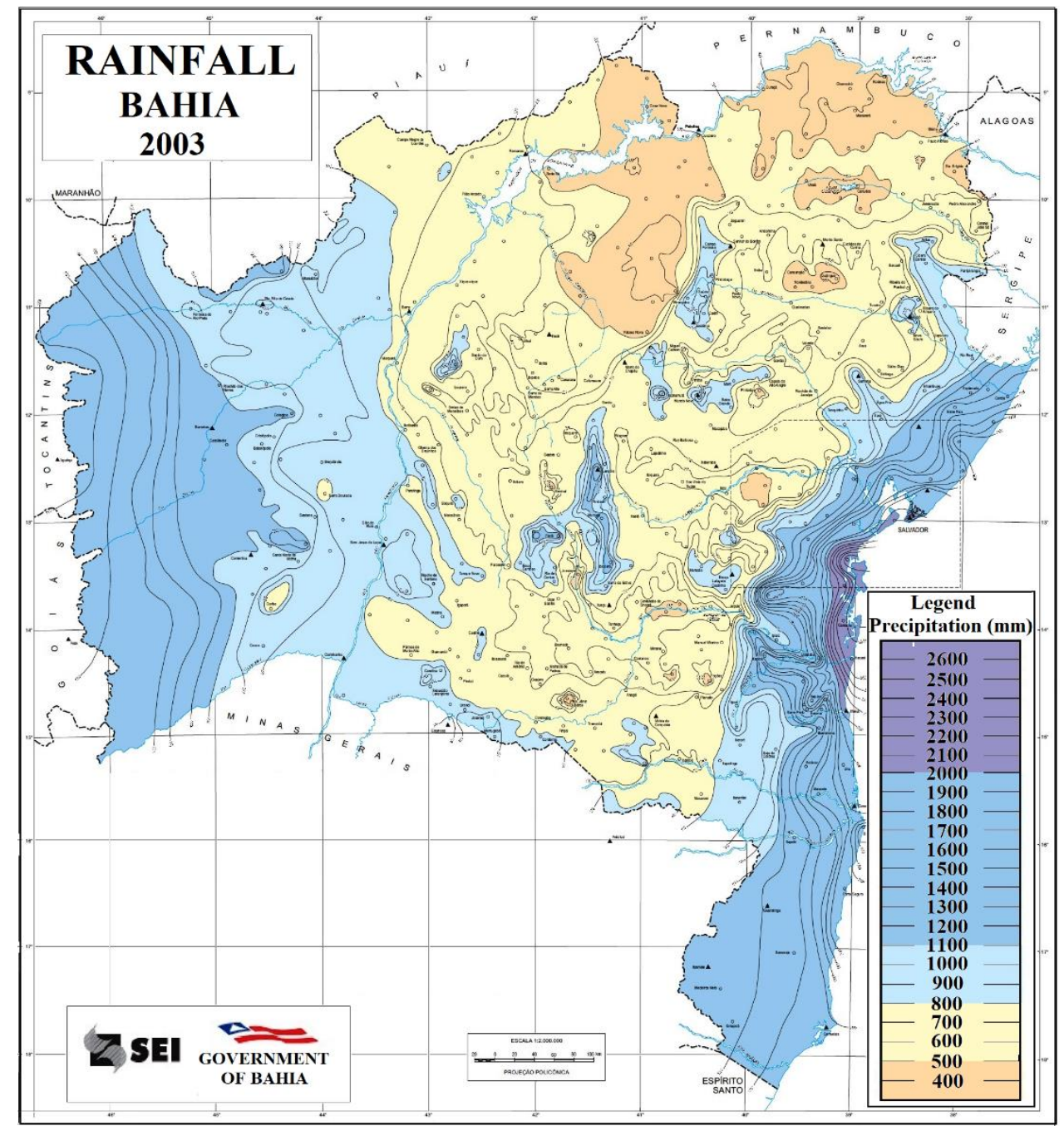

Figure 10. Pluviometric Map of Bahia State (Bahia, 2003) (Adapted). 
In order to validate the suggested proposal, a statistical study is presented in Table 5 with the mean, standard deviation and coefficient of variation (cv) of the total annual precipitation and PCD for each cluster. According to the researched literature, there is no consensus regarding the homogeneity degree of the sample from the coefficient of variation. The criterion described in Ferreira (1991) will be adopted, in which values of cv up to $20 \%$ guarantee a good representativeness, until $30 \%$ the results are regulars and from this there is high dispersion of the data.

Table 5. Statistical study to the new clusters.

\begin{tabular}{ccccccc}
\hline Cluster & $\begin{array}{c}\text { Mean } \\
\text { Precipitation }\end{array}$ & $\begin{array}{c}\text { Standard } \\
\text { Deviation }\end{array}$ & $\begin{array}{c}\text { Coefficient of } \\
\text { Variation }\end{array}$ & $\begin{array}{c}\text { Mean } \\
\text { PCD }\end{array}$ & $\begin{array}{c}\text { Standard } \\
\text { Deviation }\end{array}$ & $\begin{array}{c}\text { Coefficient } \\
\text { of Variation }\end{array}$ \\
\hline $\mathbf{1}$ & 1386,51 & 386,35 & $28 \%$ & 0,20 & 0,09 & $45 \%$ \\
$\mathbf{2}$ & 513,17 & 94,52 & $18 \%$ & 0,61 & 0,04 & $6 \%$ \\
$\mathbf{3}$ & 991,68 & 64,47 & $7 \%$ & 0,61 & 0,02 & $3 \%$ \\
$\mathbf{4}$ & 1293,30 & 173,46 & $13 \%$ & 0,11 & 0,05 & $45 \%$ \\
$\mathbf{5}$ & 655,63 & 147,17 & $22 \%$ & 0,36 & 0,12 & $33 \%$ \\
$\mathbf{6}$ & 628,59 & 78,46 & $12 \%$ & 0,45 & 0,13 & $28 \%$ \\
$\mathbf{7}$ & 838,77 & 103,93 & $12 \%$ & 0,28 & 0,04 & $14 \%$ \\
$\mathbf{8}$ & 746,66 & 85,33 & $11 \%$ & 0,60 & 0,02 & $3 \%$ \\
$\mathbf{9}$ & 482,15 & 144,44 & $30 \%$ & 0,25 & 0,10 & $40 \%$ \\
$\mathbf{1 0}$ & 690,80 & 171,93 & $25 \%$ & 0,20 & 0,08 & $40 \%$ \\
\hline
\end{tabular}

When analyzing Table 5, an optimum homogeneity is verified for the proposed groupings. In five of these, however, the cv was greater than $30 \%$ for PCD. However, it is known that the PCD is very sensitive to the data, since it varies from 0 to 1 . In order to study the PCD for these groupings, it was decided to find the maximum and minimum values of this quantity for their stations. The values found are described in Table 6.

Table 6. Amplitude of the PCD value for some clusters.

\begin{tabular}{ccc}
\hline Cluster & Maximum PCD & Minimum PCD \\
\hline $\mathbf{1}$ & 0,35 & 0,06 \\
$\mathbf{4}$ & 0,31 & 0,04 \\
$\mathbf{5}$ & 0,62 & 0,15 \\
$\mathbf{9}$ & 0,40 & 0,08 \\
$\mathbf{1 0}$ & 0,36 & 0,12 \\
\hline
\end{tabular}

It is observed that, in general, the maximum and minimum values are not so high. Except for Cluster 5 (which presented a peak value of 0.62), the other values are considered low, in order to characterize more uniform rains throughout the year, regardless of the magnitude value. In addition, the proposed climatic sectorization is validated.

From the validation of the proposal of sectorization of the state, it was possible to compare the obtained results with others found on literature. Braga et al. (1998), for example, determined nine groups for the State of Bahia, with some of them similar to those proposed by that research. However, analyzing Figures 2, 9 and 10 together, the South, the Southwest and the coastal region of the state became better represented by the mesoregions defined by the authors of that article, mainly on the aspect of the annual total precipitation.

Dourado et al. (2013) also defined a sectorization of the State of Bahia, also under the aspect of the annual total precipitation. The study defined five groups, half of the proposed quantity by that research. Considering that it used only 92 pluviometric stations for analysis, 
some areas of the state were not contemplated, thus reducing the efficacy of the research. Compared with the proposal of that article, the 180 employed stations managed to better represent Bahia and defined ten groups with homogenous hydric regime.

\section{CONCLUSIONS}

The study of Bahia State rainfall showed the great diversity of this phenomenon's behavior in the state. Its rain distribution was found from the PCD, PCP and Annual Total Precipitation spatialization. The great variability of these characteristics was observed for the 180 pluviometric stations studied, apart from PCP, which indicated that the precipitation of Bahia is basically concentrated between the months of November and February.

On the other hand, that article served as a theoretical base to the update of the grouping proposal of Araújo and Rodrigues (2000) which presented non-uniformity to the rainfall parameters of some pluviometric stations belonging to the same mesoregion, except for the North and the West. Therefore, Bahia becomes better-represented through the climatic sectorization with 10 groups with proven validation through a statistical treatment of the data that indicated homogeneity of the rainfall indicators (annual total precipitation and PCD) to each defined group.

\section{ACKNOWLEDGEMENTS}

The authors are grateful for the support of Fundação de Amparo à Pesquisa do Estado da Bahia (FAPESB).

\section{REFERENCES}

ANDRÉ, R. G. B. et al. Identificação de regiões pluviometricamente homogêneas no estado do Rio de Janeiro, utilizando-se valores mensais. Revista Brasileira de Meteorologia, v. 23, n. 4, p. 501-509, 2008. http://dx.doi.org/10.1590/S0102-77862008000400009

ARAÚJO, H. A.; RODRIGUES, R. S. Regiões Características do Estado da Bahia para Previsão de Tempo e Clima. Salvador: SEINFRA; SRH; GEREI, 2000.

BAHIA. Superintendência de Estudos Econômicos e Sociais. Mapa de pluviometria, Estado da Bahia. 2003. Altura: 1349 pixels. Largura: 613 pixels. Formato PDF.

BERTONI, J. C.; TUCCI, C. E. M. Precipitação. In: TUCCI, C. E. M. Hidrologia: ciência e aplicação. Porto Alegre: UFRGS, 2007. p. 177-241.

BADR, H. S. Regionalizing Africa: Patterns of Precipitation Variability in Observations and Global Climate Models. Journal of Climate, v. 29, n. 24, p. 9027-9043, 2016. https://doi.org/10.1175/JCLI-D-16-0182.1

BRAGA, C. C.; MELO, M. L. D.; MELO, E. C. S. Análise de Agrupamento Aplicada a Distribuição da Precipitação no Estado da Bahia. In: CONGRESSO DE METEOROLOGIA, 10.; CONGRESSO DE FLISMET, 8., 1998. Anais... Brasília - DF, 1998.

CENTRO DE PREVISÃO DE TEMPO E ESTUDOS CLIMÁTICOS. Instituto Nacional de Pesquisas Espaciais. Climanálise: Boletim de Monitoramento e Análise Climática, n. especial, 1986.

DOURADO, C. S.; OLIVEIRA, S. R. M.; AVILA, A. M. H. Análise de zonas homogêneas em séries temporais de precipitação no Estado da Bahia. Bragantia, v. 72, n. 2, p. 192-198, 2013. http://dx.doi.org/10.1590/S0006-87052013000200012 
FERREIRA, P. V. Estatística experimental aplicada à agronomia. Maceió: EDUFAL, 1991.

FIRAT, M. et al. Classification of Annual Precipitations and Identification of Homogeneous Regions using K-Means Method. Teknik Dergi, v. 23, n. 115, p, 1609-1622, 2012.

FREITAS, J. C. Análise de Agrupamentos na Identificação de Regiões Homogêneas de Índices Climáticos no Estado da Paraíba, PB-Brasil. Revista Brasileira de Geografia Física, v. 6, n. 4, p. 732-748, 2013.

GUEDES, R. V. S.; SOUSA, S. S.; SOUSA, F. A. S. Uso da entropia e da análise de agrupamento na avaliação da disponibilidade potencial de recursos hídricos do Nordeste do Brasil. Revista Ambiente \& Água, v. 5, n. 2, p. 175-187, 2010. https://doi.org/10.4136/ambi-agua.146

GÖPFERT, H.; ROSSETTI, L. A.; SOUZA, J. Eventos generalizados e seguridade agrícola. Brasília: IPEA, 1993. 65p.

KELLER FILHO, T.; ASSAD, E. D.; LIMA, P. R. S. R. Regiões pluviometricamente homogêneas no Brasil. Pesquisa Agropecuária Brasileira, v. 40, n. 4, p. 311-322, 2005. http://dx.doi.org/10.1590/S0100-204X2005000400001

KOUSKY, V. E. Frontal influences on northeast Brazil. Monthly Weather Review, v. 107, n. 9, p. 1140-1153, 1979. https://doi.org/10.1175/1520-0493(1979)107<1140:FIONB>2.0.CO;2

KYSELÝ, J.; PICEK, J.; HUTH, R. Formation of homogeneous regions for regional frequency analysis of extreme precipitation events in the Czech Republic. Studia Geophysica et Geodaetica, v. 51, n. 2, p. 327-344, 2007. https://doi.org/10.1007/s11200-007-0018-3

OLIVEIRA-JÚNIOR, J. F. et al. Cluster analysis identified rainfall homogeneous regions in Tocantins state, Brazil. Bioscience Journal, v. 33, n. 2, p. 333-340, 2017. https://doi.org/10.14393/BJ-v33n2-32739

PAULHUS, J. L. H.; KOHLER, M. A. Interpolation of missing precipitation records. Monthly Weather Review, v. 80, n. 8, p. 129-133, 1952. https://doi.org/10.1175/15200493(1952)080<0129:IOMPR>2.0.CO;2

SILVA, G. B.; SOUZA, W. M.; AZEVEDO, P. V. Cenários de Mudanças Climáticas no Estado da Bahia através de Estudos Numéricos e Estatísticos. Revista Brasileira de Geografia Física, v. 05, n. 05, p. 1019-1034, 2012.

TEODORO, P. E. et al. Cluster analysis applied to the spatial and temporal variability of monthly rainfall in Mato Grosso do Sul State, Brazil. Meteorology and Atmospheric $\begin{array}{lllllll}\text { Physics, } & \text { v. } & 128, & \text { n. } & 2, & \text { p. } & 197-209,\end{array}$ http://onlinelibrary.wiley.com/doi/10.1002/joc.3926/

TERASSI, P. M. B.; GALVANI, E. Identification of Homogeneous Rainfall Regions in the Eastern Watersheds of the State of Paraná, Brazil. Climate, v. 5, n. 3, p. 53, 2017. https://doi.org/10.3390/cli5030053

WARD, J. H. Hierarchical grouping to optimize an objective function. Journal American Association, v. 58, p. 236-244, 1963. https://doi.org/10.1080/01621459.1963.10500845

XUMEI, L. et al. Spatial and temporal variability of precipitation concentration index, concentration degree and concentration period in Xinjiang, China. International Journal of Climatology. v. 31, p. 1679-1693, 2010. 